University of Nebraska - Lincoln

DigitalCommons@University of Nebraska - Lincoln

USDA National Wildlife Research Center - Staff Publications
U.S. Department of Agriculture: Animal and Plant Health Inspection Service

2021

\title{
Landscape use by fishers (Pekania pennanti): core areas differ in habitat than the entire home range
}

Jennifer R. Kordosky

Eric M. Gese

Craig M. Thompson

Patricia A. Terletzky

Kathryn L. Purcell

See next page for additional authors

Follow this and additional works at: https://digitalcommons.unl.edu/icwdm_usdanwrc

Part of the Natural Resources and Conservation Commons, Natural Resources Management and Policy Commons, Other Environmental Sciences Commons, Other Veterinary Medicine Commons, Population Biology Commons, Terrestrial and Aquatic Ecology Commons, Veterinary Infectious Diseases Commons, Veterinary Microbiology and Immunobiology Commons, Veterinary Preventive Medicine, Epidemiology, and Public Health Commons, and the Zoology Commons

This Article is brought to you for free and open access by the U.S. Department of Agriculture: Animal and Plant Health Inspection Service at DigitalCommons@University of Nebraska - Lincoln. It has been accepted for inclusion in USDA National Wildlife Research Center - Staff Publications by an authorized administrator of DigitalCommons@University of Nebraska - Lincoln. 
Authors

Jennifer R. Kordosky, Eric M. Gese, Craig M. Thompson, Patricia A. Terletzky, Kathryn L. Purcell, and Jon D. Schneiderman 


\title{
Landscape use by fishers (Pekania pennanti): core areas differ in habitat than the entire home range
}

\author{
Jennifer R. Kordosky, Eric M. Gese, Craig M. Thompson, Patricia A. Terletzky, Kathryn L. Purcell, \\ and Jon D. Schneiderman
}

\begin{abstract}
Home ranges have long been studied in animal ecology. Core areas may be used at a greater proportion than the rest of the home range, implying the core contains dependable resources. The Pacific fisher (Pekania pennanti (Erxleben, 1777)) is a rare mesocarnivore occupying a small area in the Sierra Nevada Mountains, California, USA. Once statewide, fishers declined in the 1900s due to trapping, habitat fragmentation, and development. Recently, drought induced by climate change may be affecting this population. We examined space use of fishers in their core versus their home range for levels of anthropogenic modifications (housing density, road density, silvicultural treatments), habitat types, and tree mortality. We found core areas contained more late-successional forest and minimal human activity compared with their territory. Their core had higher levels of dense canopy and higher amounts of conifer cover, while minimizing the amount of buildings, developed habitat, and low canopy cover. Fishers may in effect be seeking refugia by minimizing their exposure to these elements in their core. Conserving landscape components used by fishers in their core areas will be important for the persistence of this isolated population.
\end{abstract}

Key words: anthropogenic, core area, fisher, landscape, Pekania pennanti, refugia.

Résumé : Les domaines vitaux sont étudiés depuis longtemps en écologie animale. Les aires principales pourraient être utilisées en plus grande proportion que le reste du domaine vital, ce qui sous-entend qu'elles renferment des ressources fiables. Le pékan (Pekania pennanti (Erxleben, 1777)) est un mésocarnivore rare qui occupe une petite région de la chaîne des Sierra Nevada, en Californie (États-Unis). Autrefois présents dans l'ensemble de l'État, les pékans ont connu un déclin au $20^{\mathrm{e}}$ siècle causé par le piégeage, la fragmentation de leurs habitats et l'aménagement du territoire. Des sécheresses récentes induites par les changements climatiques pourraient avoir une incidence sur cette population. Nous avons comparé l'utilisation de l'espace par les pékans dans leurs aires principales et dans leurs domaines vitaux pour différents degrés de modifications d'origine humaine (densité de logement, densité de routes, traitements sylvicoles), types d'habitats et taux de mortalité des arbres. Nous avons constaté que les aires principales des pékans renferment plus de forêts en fin de succession et très peu d'activités humaines comparativement à l'ensemble de leur territoire. Les aires principales présentent de plus grandes proportions de canopée dense et de plus grandes quantités de couvert de conifères, alors que la quantité de bâtiments, les habitats aménagés et le couvert forestier bas y sont très limités. Les pékans pourraient en fait chercher des refuges en minimisant leur exposition à ces éléments dans leur aire principale. La conservation d'éléments du paysage utilisés par les pékans dans leurs aires principales sera importante pour la persistance de cette population isolée. [Traduit par la Rédaction]

Mots-clés : origine humaine, aire principale, pékan, paysage, Pekania pennanti, refuge.

\section{Introduction}

Climate change and anthropogenic modifications to the landscape can directly and indirectly affect wildlife (Wingfield 2008, 2013; Rangel-Negrin et al. 2009). In the Sierra Nevada Mountains of California, USA, a 4-year drought and a mountain pine beetle (Dendroctonus ponderosae Hopkins, 1902) infestation have drastically impacted the forest through tree mortality followed by increased fire activity and severity (Bart et al. 2016). Climate change has been shown to increase the severity and frequency of droughts and insect outbreaks (Dale et al. 2001; Allen et al. 2010), and has the potential to influence tree health. In addition, anthropogenic changes to the forest, such as expansion of developed areas, logging, prescribed burning, and restoration activities, have created a highly fragmented and constantly changing forest (Franklin and Fites-Kaufman 1996; Heilman et al. 2002). Climate change and anthropogenic modifications to the landscape may be working together to create a novel landscape that fishers have not evolved to. This makes understanding habitat use increasingly important. As climate change and anthropogenic alterations expand throughout the world, it becomes increasingly

Received 12 April 2020. Accepted 1 August 2020.

J.R. Kordosky and P.A. Terletzky. Department of Wildland Resources, Utah State University, Logan, UT 84322, USA.

E.M. Gese. U.S. Department of Agriculture, Wildlife Services, National Wildlife Research Center, Department of Wildland Resources, Utah State University, Logan, UT 84322, USA.

C.M. Thompson. U.S. Department of Agriculture, Forest Service, Region 1, Missoula, MT 59804, USA.

K.L. Purcell. U.S. Department of Agriculture, Forest Service, Pacific Southwest Research Station, Fresno, CA 93710, USA.

J.D. Schneiderman. Great Basin Institute, Reno, NV 89511, USA.

Corresponding author: Eric M. Gese (email: eric.gese@usu.edu).

Copyright remains with the author(s) or their institution(s). Permission for reuse (free in most cases) can be obtained from copyright.com. 
important to monitor threatened and endangered species affected by the constantly changing environment (Hoegh-Guldberg et al. 2008), and to both identify and conserve areas of frequent use for threatened species.

Home ranges have been defined as the area used by an individual during its normal activities, such as gathering food, resting, mating, and caring for young (Burt 1943; Plowman et al. 2006). The core area of a home range may be used at a greater proportion than the rest of the home range (Burt 1943; Kaufmann 1962; Ewer 1968; Plowman et al. 2006), implying that the core contains the most dependable resources (Leuthold 1977). Food availability can also increase in core areas of territories as was found with the banded mongoose (Mungos mungo (Gmelin, 1788)) in Uganda (Gilchrist and Otali 2002). This implies that core area could serve as refugia for individuals. Managing refugia may be important for conservation in the face of climate change (Morelli et al. 2016), making identification of refugia for specialist species important for conservation.

Fishers (Pekania pennanti (Erxleben, 1777)) are territorial mesocarnivores that depend on multi-layered mature forest for hunting, denning, and shelter (Douglas and Strickland 1987; Thompson et al. 2011; Zielinski et al. 2013). As mesocarnivores, fishers have various ecological roles (Roemer et al. 2009). The historic range of fishers in California has been described as a continuous arc from the Coast Range eastward to the southern Cascades, then south through the Sierra Nevada (Grinnell et al. 1937). This extent has been reduced due to fur trapping, forest fragmentation, and habitat loss, with the result that fisher populations are at low densities in the Sierras (Schempf and White 1977). Fisher populations in California declined in the 1940s and the species was listed as a species of concern when fur trapping reduced the population close to extinction (Hall 1942). Concerns for their population size resulted in a ban on trapping in 1946 (Lewis and Zielinski 1996) from which fishers have never fully recovered. In 2005 , fishers were declared a candidate species for listing under the Endangered Species Act, but in 2016 the listing petition was withdrawn. Currently the proposed designation of the West Coast Distinct Population Segment of fishers as endangered is under review (U.S. Fish and Wildlife Service 2019). The southern Sierra Nevada population is small at $<300$ adults (Spencer et al. 2011; Tucker et al. 2017) and has likely been genetically isolated from other populations since pre-European settlement (Knaus et al. 2011; Tucker et al. 2012, 2017). Presently, factors potentially limiting recovery of the fisher in the Pacific States include climate change and anthropogenic modifications to the landscape (U.S. Fish and Wildlife Service 2014).

Concerns over the low population size in the southern Sierra Nevada of California and the perceived conflict between the persistence of fisher population(s) and fuel reduction efforts in national forests led to the initiation of two long-term studies to investigate the ecology of fishers and monitor population fluctuations: the Kings River Fisher Project (KRPF) and the Sierra Nevada Adaptive Management Project (SNAMP) (Thompson et al. 2011; Hopkinson and Battles 2015). Although the current study used a subset of the data collected since 2007, these studies radio-collared and monitored $>250$ fishers to determine habitat use, survival, and reproduction (Green et al. 2018). Results showed fishers preferred late-successional forests with dense, multi-layered tree cover (Purcell et al. 2009; Thompson et al. 2011). Recently, the combination of an extended 4-year (2012-2015) drought and infestation of mountain pine beetle has resulted in extensive tree mortality of ponderosa pine and other coniferous species with large areas of dead or dying mature trees, with tree mortality numbers reaching hundreds of dead trees per square kilometre (Young et al. 2017; Fettig et al. 2019). Kordosky (2019) found increased tree mortality due to drought and insect infestation led to an increase in physiological stress, as measured through cortisol, which had a subsequent negative influence on survival suggesting that the recent spike in tree mortality may cause fishers to avoid these effected areas. Despite these predictions, a previous study showed that management activities influenced fishers, but did not cause them to re-orient their home-range footprint (Zielinski et al. 2013); however, that study occurred in healthy forest with few dead trees, while the current study occurred in an area with many dead trees. Concurrently, Kordosky (2019) found that small-scale management activities in the forest did not influence fisher stress as measured through cortisol during the same time period.

Our objective was to determine which landscape characteristics were more abundant in the core area of a fisher territory compared with the entirety of their territory. We measured various metrics of anthropogenic modifications, habitat characteristics, and tree mortality (as a proxy for drought and mountain pine beetle response) and compared these parameters between two spatial scales of home-range use (30\% core versus $95 \%$ kernel). Core areas containing high-quality habitat and less human activity were important for space use by wolves (Canis lupus Linnaeus, 1758) (Mancinelli et al. 2018) and Canada lynx (Lynx canadensis Kerr, 1792) (Holbrook et al. 2019). We predicted that (i) fisher home ranges or territories would contain more late-successional forest in the core of their territory compared with the entire territory, and (ii) fisher territories would minimize exposure to high levels of tree mortality, anthropogenic modifications, and human presence in the core of their territory compared with the entire territory. The results of this study may help forest managers determine which areas of the forest need to be maintained as refugia to ensure fisher occupancy across the landscape, especially in the face of climate change.

\section{Materials and methods}

\section{Study area}

This study was conducted in the KRFP and SNAMP (Fig. 1) study areas located in the Sierra Nevada, California, USA. The SP study area was located in the Bass Lake Ranger District of the Sierra National Forest and was approximately $800 \mathrm{~km}^{2}$ in size, whereas the $450 \mathrm{~km}^{2}$ KR study area was located in the High Sierra District of the Sierra National Forest. The KR area was located approximately $11 \mathrm{~km}$ southeast of the SP area. During summer, precipitation was rare with maximum temperatures averaging $23^{\circ} \mathrm{C}$ and minimum temperatures averaging $9{ }^{\circ} \mathrm{C}$ (https://weather.com/ weather/monthly/1/Shaver+Lake+CA+93664:4:US). During winter, snow accumulation was typical throughout the Sierras, with both study areas having snow cover from November to April. Winter temperatures averaged a high of $7{ }^{\circ} \mathrm{C}$ and a low of $-4^{\circ} \mathrm{C}$. Both study areas were similar in elevation from 1000 to $2400 \mathrm{~m}$. The region was impacted by a 4-year (2012-2015) drought, which was thought to be the most severe drought in the region in 1200 years, resulting in high levels of tree mortality due to a combination of the drought and mountain pine beetle infestation (Fettig et al. 2019). The level of tree mortality was considered unprecedented by some (Stephens et al. 2018), with severe canopy water stress of at least 58 million trees (Asner et al. 2016; Fettig et al. 2019).

\section{Trapping and monitoring}

Trapping of fishers followed Green et al. (2018). We trapped fishers with live traps $(81.28 \mathrm{~cm} \times 25.4 \mathrm{~cm} \times 30.48 \mathrm{~cm}$; Model 108 , Tomahawk Live Trap, Hazelhurst, Wisconsin, USA) with wooden cubby shelters (Wilbert 1992; Seglund 1995). We covered traps with natural materials and baited with chicken and bait lure (Hawbaker's Fisher Lure, Hawbaker and Sons, Fort Loudon, Pennsylvania, USA, or Fisher Red Lure, Proline Lures, Indianapolis, Indiana, USA). We used distance lures (Caven's Gusto, Minnesota Trapline Products, Pennock, Minnesota, USA, or Outreach Call Lure, Proline Lures, Indianapolis, Indiana, USA) to draw animals in from farther distances. We handled fishers using a canvas sleeve and metal handling cone (Seglund 1995). We sedated animals with 
Fig. 1. Location of fisher (Pekania pennanti) study areas: Kings River Fisher Project (KRFP) and Sierra Nevada Adaptive Management Project (SNAMP), California, USA, 2014-2016. Base map image plotted with ArcGIS version 10.5 (Esri, Inc., Redlands, California, USA) using study area locations from the current study.

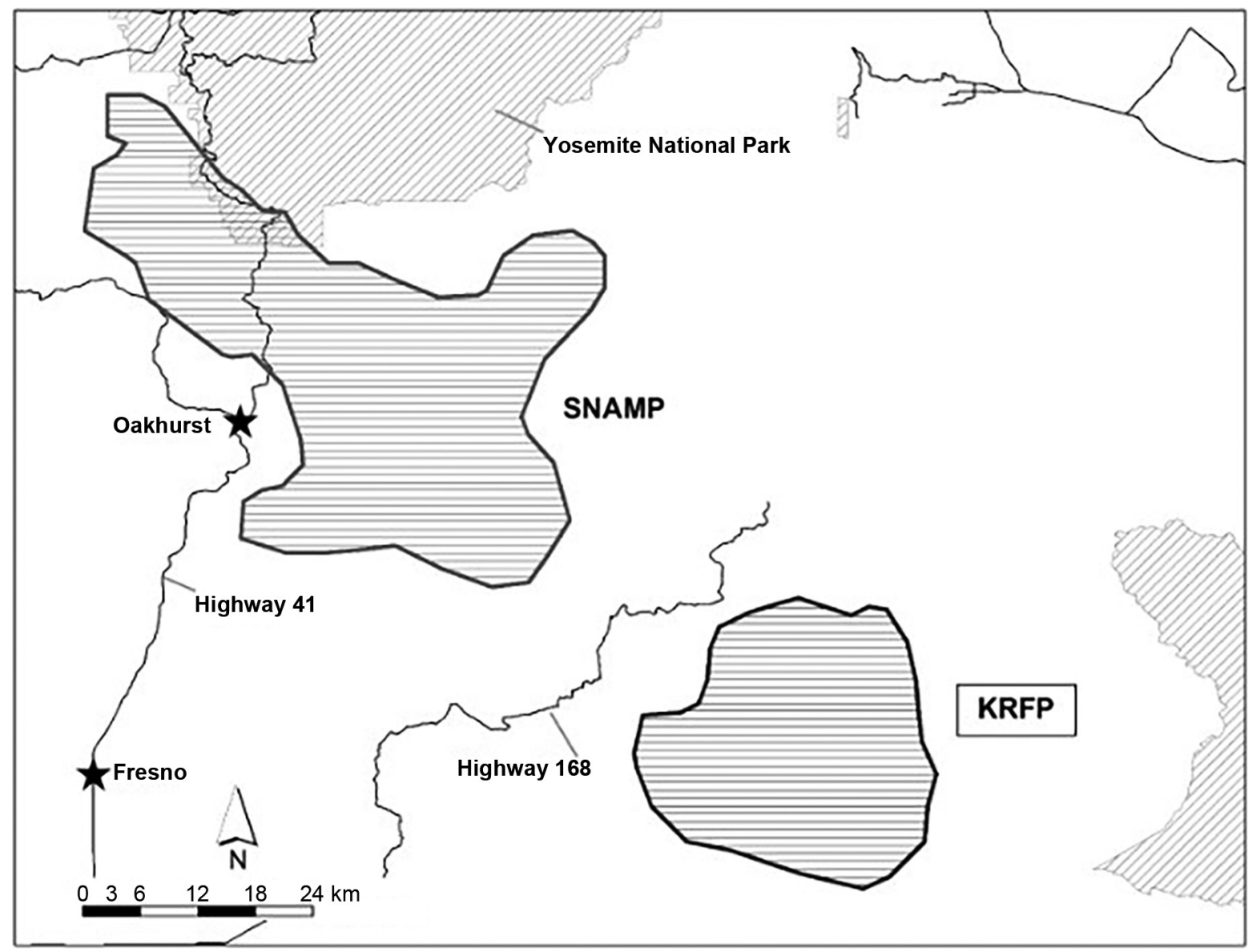

an intramuscular injection of ketamine hydrochloride $(22.5 \mathrm{mg} / \mathrm{kg})$ mixed with Diazepam or Midazolam $(0.125 \mathrm{mg} / \mathrm{kg})$, with dosages based on sex and estimated age and body mass. We measured body length, body mass, tail length, canine length, and reproductive status through teat condition and testicular size. Fishers were fitted with a VHF radio collar weighing $31 \mathrm{~g}$ (Holohil model mI-2M, Holohil Systems Ltd., Carp, Ontario, Canada) with a handmade breakaway (Thompson et al. 2011). We also injected them with a Passive Integrated Transponder (Biomark, Boise, Idaho, USA) for future identification and tracking (Green et al. 2018). Animals were captured and handled under authorization of the U.S. Forest Service with permits from California Department of Fish and Wildlife (Permit SC-2730) with Institutional Animal Care and Use Committee (IACUC) review and approval from the University of California-Davis (IACUC \#18022).

\section{Territory determination}

From 2014 to 2016, we determined annual home ranges by relocating animals through year-round monitoring, which included radio-telemetry locations, rest sites, flight locations, and den sites (Green et al. 2018). Home ranges were collected each year from 15 November 15 to 14 November of the following year. This was done to coincide with trapping season as the cutoff date. The error for these locations varied but were distributed similarly among all fishers and therefore any bias was weighted equally among all individuals. The main difference was male fishers use a larger spatial area and do not use den sites, whereas females raise the young independently. Due to these spatial and behavioral differences, we conducted separate analyses for males and females. Rest sites were defined as a single structure in which an individual was located (i.e., tree, snag, burrow). Rest areas were defined as an area (within $50 \mathrm{~m}$ ) in which an individual was located, but could not be narrowed down to one specific structure (Green et al. 2018). Locations (triangulations, rest sites, and rest areas) of female fishers were obtained approximately every 3 days, with rest site locations and rest areas collected opportunistically when searching an area. Den locations were added into the data set once for every 3 days a female was at a den; this was based on how often female fishers are typically relocated, and these locations were subsampled as to not skew the home-range estimators towards these den sites.

We used $\mathrm{R}$ (adehabitatHR package, version 3.3.0) in $\mathrm{R}$ studio (version 1.0.136; R Core Team 2016) and ArcGIS version 10.5 (Esri, Inc., Redlands, California, USA; Harris et al. 1990) to determine annual home ranges with $30 \%$ and $95 \%$ fixed kernel estimators (Worton 1989). A priori, annual home ranges were calculated with $30 \%, 60 \%$, and $95 \%$ fixed kernel estimators to compare home-range habitat across multiple scales. The $30 \%$ kernel was selected as the core area instead of the typical $50 \%$ selected in other studies (Plowman et al. 2006; De Luca et al. 2010) because we wanted to utilize a smaller core area for forest managers to potentially preserve. The $30 \%$ kernel represents the core of the individual's home range and has a $30 \%$ probability of containing the individual (Powell 2000). The core refers to the area within a home range where individuals are found with greater probability (Kaufmann 1962; White and Garrott 1990; Bŏrger et al. 2008; 
Silva-Opps and Opps 2011). Therefore, the core is an area of concentrated use within a home range (Kaufmann 1962) containing important resources such as den sites and quality foraging areas (Ewer 1968; Silva-Opps and Opps 2011). Individuals are likely more familiar with the core of their territory, while lack of familiarity can lead to increased stress (Johnson et al. 2018). This suggests that the core may serve as refugia for an individual and contain preferable habitat such as dense canopy cover and latesuccessional forest, which fishers prefer (Douglas and Strickland 1987; Thompson et al. 2011; Zielinski et al. 2013). As this is the center of the home range, individuals most likely pass through and use this area more frequently than other areas of the home range, giving them a central place to inhabit when conditions are challenging. We hypothesized that the core area habitat will vary from the entirety of the home range, and this will demonstrate the central refugia that fishers use. The 95\% kernel represents the entirety of the individual's home range and has a $95 \%$ chance of containing the individual (Powell 2000).

We calculated an area-observation curve (Laver and Kelly 2008) for each female and male fisher to determine the number of points needed to encompass their home range. We determined 25-30 points adequately described a female fisher's home range. In contrast, the area-observation curves for the males did not reach an asymptote, even with some location sample sizes $>100$. Therefore, we defined the areas the males inhabited as "areas of use" as opposed to home ranges. Furthermore, male fishers used a larger area and do not use den sites, whereas females raised their young independently in one or more reproductive dens. Due to these spatial and behavioral differences and our inability to determine the male home range, we conducted separate analyses for males and females.

\section{Anthropogenic modifications}

We obtained data layers showing where various silvicultural treatments (i.e., logging, thinning, burning, regeneration) had occurred for both areas over the 3 years (2014-2016) of sampling from the Forest Service Activity Tracking System (FACTS) database through the U.S. Department of Agriculture (https://data.fs. usda.gov/geodata/edw/datasets.php). Zielinski et al. (2013) defined which management activities impact fisher habitat, including (i) thinning of natural fuels, (ii) commercial thinning, (iii) full planting without concurrent site preparation, (iv) fill-in re-planting without concurrent site preparation, $(v)$ individual tree release and weeding, and (vi) pre-commercial thinning of individual or selected trees. We calculated the area of each of these management activities for each female home range or male area of use and standardized to square metre of activity/square kilometre of home range or area of use to determine the proportion of land each activity covered for each home range each year. We used square metre for area of management activities instead of square kilometre because some management activity areas were very small. We combined management activities into "removal" (thinning of natural fuels, commercial thinning, precommercial thinning individual or selected trees, precommercial thinning - strip) and "restoration" (full planting without concurrent site preparation, fill-in planting without concurrent site preparation) to decrease the number of variables being analyzed (Sweitzer et al. 2016b).

To assess human activity, we obtained locations of buildings and roads for both study areas from the U.S. Forest Service. We determined building density (number buildings $/ \mathrm{km}^{2}$ ) and roads $\left(\mathrm{m} / \mathrm{km}^{2}\right)$ within each female fisher's home range and each male fisher's area of use at each kernel level (i.e., 30\% and 95\% kernels). We used metre $(\mathrm{m})$ for road length instead of kilometre $(\mathrm{km})$ because some roads were $<1 \mathrm{~km}$ in length.

\section{Habitat characteristics}

We examined canopy cover and habitat type for both study areas from 2014 to 2016, as both of these variables have been found to be important for fishers (Douglas and Strickland 1987; Thompson et al. 2011; Aubry et al. 2013; Zielinski et al. 2013). We obtained canopy cover and habitat type data from the Land Fire database through the U.S. Forest Service (USFS; 2014 U.S. Department of Interior, Geological Survey). We delineated six habitat types in the study areas (Allen-Diaz et al. 2007; Keeley and Davis 2007) - (1) "conifer forest" was dominated by conifer trees, mainly ponderosa pine (Pinus ponderosa Douglas ex P. Lawson and C. Lawson), sugar pine (Pinus lambertiana Douglas), Jeffery pine (Pinus jeffreyi Balf.), white fir (Abies concolor (Gordon and Glend.) Liindl. ex Hildebr.), and incense cedar (Calocedrus decurrens (Torr.) Florin); (2) "hardwood forest" was dominated by hardwoods including California black oak (Quercus kelloggii Newberry) and canyon live oak (Quercus chrysolepis Liebm.) or was a combination of conifer and hardwood forest; (3) "developed land" were areas with human development such as buildings and houses; (4) "shrubland" were areas dominated by shrubs, mainly manzanita (genus Arctostaphylos Adans.), whitethorn ceanothus (Ceanothus cordulatus Kellogg), and bear clover or mountain misery (Chamaebatia foliolosa Benth.); (5) "sparse cover" were areas with granite or little shrub cover; (6) "open water" was areas of open water. Although "open water" was a unique category, we did not analyze open water as fishers do not use these areas. We measured the percent habitat type per home range or area of use at each kernel estimator.

In late-successional forest, dense canopy cover has previously been characterized as $\geq 60 \%$ canopy cover in California (Thompson et al. 2011; Sweitzer et al. 2016b). Canopy cover or canopy density is the single habitat feature that has been universally associated with presence of fishers and indicative of high-quality fisher habitat in California (Davis et al. 2007; Spencer et al. 2011; Aubry et al. 2013; Sweitzer et al. 2016b). Dense canopy cover is important for foraging (Zhao et al. 2012), rest site selection (Purcell et al. 2009), and refuge from larger predators (Wengert et al. 2014; Sweitzer et al. 2016a, 2016b). Therefore, we divided canopy cover into three classes: $\geq 60 \%$ (dense cover), $40 \%-59 \%$ (moderate cover), and $\leq 40 \%$ (low cover). Similar to habitat type, we calculated the percentage of each canopy coverage category (i.e., dense, moderate, low) for each home range or area of use at each kernel estimator.

\section{Tree mortality}

The combination of a 4-year (2012-2015) drought and infestation of mountain pine beetle resulted in extensive tree mortality of ponderosa pine and other conifers with large areas of dead or dying mature trees with mortality reaching hundreds of dead trees per square kilometre (Young et al. 2017). We obtained tree mortality data from the U.S. Department of Agriculture Region 5 Remote Sensing Lab (https://www.fs.usda.gov/detail/catreemortality/ toolkit/?cid=fseprd498067) and intersected this data layer with the home ranges and areas of use using Arc GIS. We measured tree mortality as the number of dead trees/acre. Although acres are not a unit of measurement typically used in scientific literature, we used acres since forest managers generally use this metric. The tree mortality data was limited in that it represented broad patterns of tree mortality since it was collected from an aerial detection survey. Within any individual polygon, there can be a fair amount of variability in the spatial distribution and severity of tree mortality, but it was the only data layer available. Data on tree mortality were available from 2015 and 2016, but not in 2014 . Therefore, tree mortality was only analyzed for 2 years $(2015,2016)$, while all other data were analyzed for 3 years $(2014,2015,2016)$.

\section{Statistical analysis}

We tested for normality of our data sets and used independent two-group $t$ tests to determine whether individual measures of anthropogenic disturbance and habitat types were significantly different among the two kernel home-range estimators (i.e., $30 \%$ core versus $95 \%$ kernel). We used $\mathrm{R}$ (version 3.3.0) in R studio (version 1.0.136) ( $\mathrm{R}$ Core Team 2016) for statistical analysis. We 
Fig. 2. Relocations and 30\% core area (solid line) and 95\% kernel home range (broken line) for three female fishers (Pekania pennanti) (F16, F33, F48), Kings River, California, USA, 2014-2016. Locational data for the three animals were obtained from the current study.

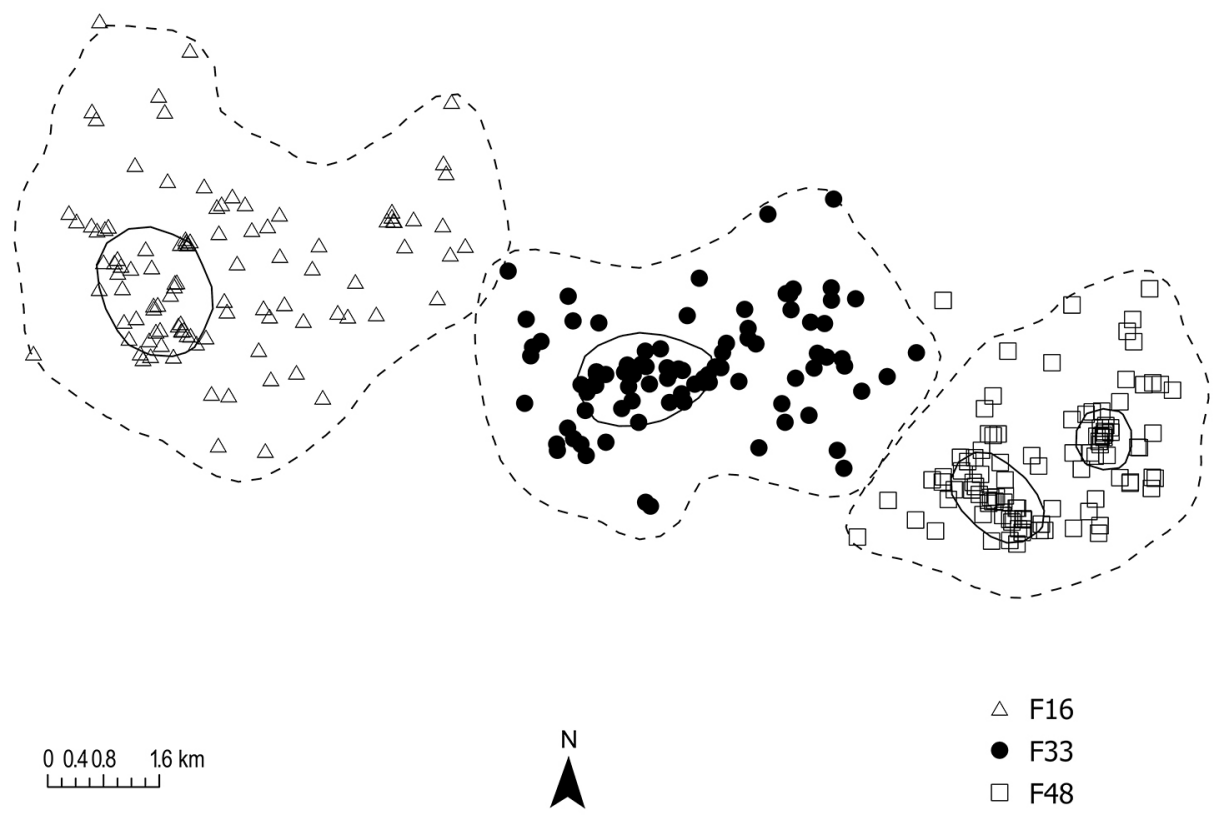

evaluated statistical significance based on a $\alpha$ of 0.10 and corrected for multiple tests using a Bonferroni adjustment (value of $P \leq 0.0077$ to account for multiple (13) comparisons). We assessed both levels of significance and drew conclusions based on overall patterns. Although spatial correlation exists between the $30 \%$ and the 95\% kernels, since the 95\% kernel encompasses the $30 \%$ kernel, this was the most appropriate way to compare the core area verses the entirety of the home range or area of use. Correlation between variable was tested and correlated variables were removed from analyses. Although low, moderate, and high canopy cover were correlated, independent $t$ tests were performed on each to determine fisher use across all three canopy cover levels.

\section{Results}

Over three winter trapping seasons (2014-2016), we captured 41 female fishers (KR: 22; SP: 19) and 23 males (KR:10; SP: 13) with some individuals captured multiple years, producing 68 annual home ranges for female fishers (KR: 44; SP: 24) (1 juvenile, 13 subadults, 54 adults) and 32 annual areas of use for male fishers (KR: 19; SP: 13) (1 juvenile, 7 subadults, 24 adults). For each year, we calculated only one home range or area of use per individual to use in the analyses. However, some animals were captured every year of the study for a total of three different territories. In the study areas, 21 females were captured 1 year, 12 females were captured 2 years, and 8 females were captured 3 years; 16 males were captured 1 year, 5 males were captured 2 years, and 2 males were captured all 3 years. For female fishers, the mean $( \pm$ SD) $30 \%$ core area averaged $1.92 \pm 1.88 \mathrm{~km}^{2}$, which was nestled (Fig. 2) in the much larger mean $( \pm S D)$ 95\% kernel home range that averaged $21.82 \pm 18.16 \mathrm{~km}^{2}$. Among male fishers, the mean ( \pm SD) $30 \%$ core area averaged $9.28 \pm 7.30 \mathrm{~km}^{2}$, whereas the mean $( \pm \mathrm{SD}) 95 \%$ area of use averaged $88.56 \pm 54.79 \mathrm{~km}^{2}$. Females averaged $91.8 \pm$ 32.5 locations/year (mean $\pm \mathrm{SD}$; median $=93$ ), whereas males averaged $75.1 \pm 32.0$ locations/year $($ median $=72.5$ ).

For female fishers, building density $(t=-3.029, \mathrm{df}=122.350$, $P=0.003)$ and percentage of low canopy cover $(t=-3.728$, $\mathrm{df}=$ 128.480, $P=0.0003)$ were significantly $(P<0.007)$ lower, whereas the percentage of dense canopy cover $(t=2.947$, $\mathrm{df}=121.960$, $P=0.004$ ) was significantly higher in core areas compared with the $95 \%$ kernel of use (Table 1). At the 0.10 significance level, the percentage of conifer forest $(t=2.582, \mathrm{df}=131.550, P=0.011)$ and percentage of dense canopy cover were higher in the core area compared with the entire territory (Table 1), and building density, percentage of hardwood habitat $(t=-2.163$, $\mathrm{df}=135.860$, $P=0.032)$, percentage of sparse cover $(t=-1.862, \mathrm{df}=130.890$, $P=0.065)$, and percentage of moderate canopy cover $(t=-1.692$, $\mathrm{df}=106.970, P=0.094)$ were all lower in the core area compared with the entire territory (Table 1 ).

For male fishers, we found a significantly $(P<0.007)$ lower portion of developed land in the $30 \%$ core compared with the $95 \%$ kernel $(t=-3.910$, $\mathrm{df}=35.918, P=0.0004$; Table 2$)$. Several other variables differed at the 0.10 level including building density $(t=-2.684, \mathrm{df}=54.740, P=0.010)$, percentage of conifer forest $(t=$ 1.841, df $=54.910, P=0.071)$, percentage of dense canopy cover $(t=2.059, \mathrm{df}=52.806, P=0.044)$, percentage of low canopy cover $(t=-2.302, \mathrm{df}=61.521, P=0.025)$, and percentage of shrubland cover $(t=-1.895, \mathrm{df}=55.949, P=0.063)$. The percentage of conifer forest and percentage of dense canopy cover were higher in the core area compared with the $95 \%$ area of use. Building density, percentage of shrubland, percentage of developed habitat, and percentage of low canopy cover were lower in the core area compared with the entire area of use suggesting that males positioned their core area to avoid developed habitat with low canopy cover.

\section{Discussion}

Female home ranges had lower amounts of building density, percentage of hardwood forest, percentage of sparse cover, percentage of moderate canopy cover, and percentage of low canopy cover within the core, while having higher amounts of conifer forest and dense canopy cover within the core area. This shows that female fishers use areas with dense coniferous forest for the core of their home range. At the same time, the core area served as refugia from less desirable areas containing buildings and low canopy cover. Similarly, male fisher areas of use had lower amounts of building density, shrubland, developed areas, and areas with low canopy cover within their core areas of use, and higher amounts of conifer forest and dense canopy cover in their core. Like the females, male fishers appeared to seek refuge in 
Table 1. Metrics (mean \pm SD) of anthropogenic modifications, habitat, and climate change across the $30 \%$ core area and the 95\% kernels for home ranges of female fishers (Pekania pennanti), Sierra National Forest, California, USA, 2014-2016.

\begin{tabular}{lllll}
\hline Variable & $30 \%$ Core area & $\begin{array}{l}95 \% \text { Kernels for home } \\
\text { range }\end{array}$ & $t$ & $P$ \\
\hline Building density $\left(\mathrm{no} . / \mathrm{km}^{2}\right)$ & $0.18 \pm 0.56$ & $0.54 \pm 0.79$ & -3.029 & $0.003^{* *}$ \\
Road density $\left(\mathrm{m}\right.$ of road $\left./ \mathrm{km}^{2}\right)$ & $1781.66 \pm 1231.21$ & $2052.79 \pm 633.99$ & -1.626 & 0.107 \\
Tree mortality $($ no. of dead trees/acre) & $22.11 \pm 24.98$ & $20.48 \pm 21.47$ & 0.314 & 0.755 \\
Percentage of conifer & $85.18 \pm 10.33$ & $81.01 \pm 8.58$ & 2.582 & $0.011^{*}$ \\
Percentage of developed habitat & $0.06 \pm 0.49$ & $0.17 \pm 0.45$ & -1.437 & 0.153 \\
Percentage of hardwood & $8.21 \pm 7.94$ & $11.12 \pm 7.69$ & -2.168 & $0.032^{*}$ \\
Percentage of shrubland & $5.43 \pm 5.12$ & $5.89 \pm 2.39$ & -0.674 & 0.502 \\
Percentage of sparse & $1.11 \pm 1.82$ & $1.80 \pm 2.33$ & -1.919 & $0.057^{*}$ \\
Percentage of low canopy cover & $8.44 \pm 7.36$ & $13.80 \pm 9.42$ & -3.728 & $0.001^{* *}$ \\
Percentage of moderate canopy cover & $46.63 \pm 19.27$ & $51.13 \pm 10.81$ & -1.692 & $0.094^{*}$ \\
Percentage of dense canopy cover & $44.84 \pm 22.99$ & $34.88 \pm 16.15$ & 2.947 & $0.004^{* *}$ \\
Restoration $\left(\mathrm{m}^{2} / \mathrm{km}^{2}\right)$ & $2980.07 \pm 20425.30$ & $2296.35 \pm 11225.24$ & 0.242 & 0.809 \\
Removal $\left(\mathrm{m}^{2} / \mathrm{km}^{2}\right)$ & $10942.08 \pm 38185.12$ & $10802.43 \pm 28305.06$ & 0.024 & 0.981 \\
\hline
\end{tabular}

Note: Biological significance $(P \leq 0.10)$ among kernels denoted with an asterisk (*). Statistical significance $(P \leq 0.007)$ among kernels denoted with a double asterisk $(* *)$.

Table 2. Metrics (mean \pm SD) of anthropogenic modifications, habitat, and drought response across the $30 \%$ core area and $95 \%$ kernels for areas of use for male fishers (Pekania pennanti), Sierra National Forest, California, USA, 2014-2016.

\begin{tabular}{lllll}
\hline Variable & 95\% Kernels for areas & & \\
\hline Building density $\left(\mathrm{no} . / \mathrm{km}^{2}\right)$ & of use & $2.38 \pm 2.85$ & -2.684 & $0.010^{*}$ \\
Road density $\left(\mathrm{m}\right.$ of road $\left./ \mathrm{km}^{2}\right)$ & $0.74 \pm 1.94$ & $2000.89 \pm 601.97$ & -1.106 & 0.274 \\
Tree mortality (no. of dead trees/acre) & $1799.49 \pm 836.38$ & $16.93 \pm 12.76$ & 0.033 & 0.974 \\
Percentage of conifer & $82.54 \pm 9.37$ & $78.84 \pm 6.43$ & 1.841 & $0.071^{*}$ \\
Percentage of developed habitat & $0.05 \pm 0.21$ & $0.58 \pm 0.74$ & -3.910 & $0.0004^{* *}$ \\
Percentage of hardwood & $8.57 \pm 8.93$ & $9.73 \pm 5.19$ & -0.624 & 0.536 \\
Percentage of shrubland & $5.95 \pm 3.08$ & $7.22 \pm 2.19$ & -1.895 & $0.063^{*}$ \\
Percentage of sparse & $2.88 \pm 3.45$ & $3.31 \pm 2.85$ & -0.525 & 0.601 \\
Percentage of low canopy cover & $15.15 \pm 10.36$ & $20.86 \pm 9.48$ & -2.302 & $0.025^{*}$ \\
Percentage of moderate canopy cover & $47.41 \pm 14.30$ & $50.11 \pm 6.57$ & -0.972 & 0.337 \\
Percentage of dense canopy cover & $37.38 \pm 20.75$ & $28.41 \pm 13.31$ & 2.059 & $0.044^{*}$ \\
Restoration $\left(\mathrm{m}^{2} / \mathrm{km}^{2}\right)$ & $640.23 \pm 2278.45$ & $1089.08 \pm 3612.75$ & -0.585 & 0.561 \\
Removal $\left(\mathrm{m}^{2} / \mathrm{km}^{2}\right)$ & $11118.74 \pm 29134.01$ & $10564.67 \pm 19066.17$ & 0.089 & 0.930 \\
\hline
\end{tabular}

Note: Biological significance $(P \leq 0.10)$ among kernels denoted with an asterisk $\left(^{*}\right)$. Statistical significance $(P \leq 0.007)$ among kernels denoted with a double asterisk $\left.{ }^{(* *}\right)$.

core areas that reduced their exposure to buildings, development, and low canopy cover.

These results show that both female and male fishers use core areas containing higher amounts of dense forest in the core of their territories and may be using these areas as refugia from human presence and less ideal fisher habitat. Past logging and fire suppression, and more recently, wildfires and climate change have led to a higher density of small-diameter trees and a reduction of large-diameter trees and logs (McKelvey and Johnston 1992), leading to reduced habitat quality, increased fragmentation, and an increased threat of high severity fires (Manley et al. 2017). With healthy conifer forest disappearing from the landscape and the threat of high severity wildfires growing (Fettig et al. 2019), fishers may struggle to find refuge from habitat fragmentation, human presence, and climate change in the future.

Although many carnivore studies have examined the use of core areas (Plowman et al. 2006; De Luca et al. 2010; Asensio et al. 2012), relatively few have examined the role core areas could serve to provide refugia in the face of climate change today regarding mesocarnivores. Furthermore, different species have varying habitat needs. Species such as wolves and cougars (Puma concolor (Linnaeus, 1771)) may do well in areas with well-distributed refugia across the landscape, where species such as wolverine and grizzly bears (Ursus arctos Linnaeus, 1758) may need areas dominated by larger or more contiguous refugia (Weaver et al. 1996). Carroll (2007) found climate change will likely lead to a decline in marten (Martes americana (Turton, 1806)) and lynx populations in southeastern Canada due to a greater decline in refugium habitats than effects of logging or trapping. This suggests habitat protection from climate change may become increasingly important to maintain and to identify for species of concern, particularly carnivores with well-defined habitat needs. Identifying core habitat may be the first step to finding refugia for fishers in the Sierra Nevada.

We found fisher territories contained higher percentages of dense canopy cover in the core of their territories, and that fishers reduced their exposure to human activities in the core, suggesting that they are using this core area as refugia from human presence. This partially contradicts the study by Sauder and Rachlow (2015) that reported fishers in the Rocky Mountains preferred heterogeneity in the core areas with more edge, but was similar with high canopy cover in the core area of their home range. The presence of snowshoe hares (Lepus americanus Erxleben, 1777) in the Rocky Mountain region, a preferred prey species for fishers, may drive this difference since snowshoe hares use 
late stand initiation forest structure with dense conifer cover (Holbrook et al. 2016), and the presence of this habitat type within a mature forest matrix may contribute to fisher habitat selection in that region. In contrast, snowshoe hares are not present in the Sierra Nevada. Instead, fishers in the Sierra Nevada have a more diverse diet, relying on smaller bodied prey more frequently found in older multi-story forests (Zielinski et al. 1999). This difference in habitat use could also be due to differences in the time of year between the two studies, habitat differences, predator abundance, or differences in human density.

Our results suggest that fishers are not avoiding small-scale silvicultural modifications (largest area modified in the home ranges was $59700.46 \mathrm{~m}^{2}$ ) in the core of their territories, which supports what other studies have found, that animals can adapt and maybe even benefit from some forms of anthropogenic modifications (Arnould et al. 2015). No large-scale management activities occurred during the years of this study. Sweitzer et al. (2016a) suggested that managers should actively maintain quality fisher habitat around reproductive dens to decrease mortality rates of reproductive females and kits. Small-scale management actions could be easily avoided by fishers and may therefore not lead to conflict or stressful situations in areas impacted by human activity and silvicultural practices.

Zielinski et al. (2013) and Sweitzer et al. (2016b) showed fishers may tolerate small amounts of forest management on the landscape, if the spatial scale of fuel reduction did not impede movements. In contrast, tree mortality was severe in both study areas, with mortality of ponderosa pines exceeding $80 \%$ in some areas (Young et al. 2017), making these areas difficult to avoid. Climate change is known to increase the severity and frequency of droughts (Dale et al. 2001; Allen et al. 2010), which will undoubtedly influence late-successional forests in the future. The effects of drought and insect infestation (i.e., tree mortality) are unavoidable among fishers because tree mortality was incredibly pervasive in these study areas. This may explain why there was no difference in the amount of tree mortality found in the core and entirety of the fisher territories; there was very little habitat available that lacked tree mortality.

We found no difference in the amount of tree mortality within the core of the fisher territories, potentially due to the limitations in the data only representing broad patterns of tree mortality. This lack of difference could also be because areas without high levels of tree mortality are now scarce on the landscape. The increase in tree mortality has been rapid (Fettig et al. 2019) over the last few years, giving individuals little time to adapt or acclimate (Levine 2000). Our results showed male and female fishers prefer higher amounts of dense canopy cover in their core area that may serve as refugia. If tree mortality continues to increase in the future, then fishers will likely have less access to dense canopy cover that provides both food and cover. Tree mortality due to drought and mountain pine beetle infestation in the Sierra Nevada Mountains is a possible metric of climate change because climate change is known to increase the severity of droughts and insect infestations (Dale et al. 2001; Allen et al. 2010). Levels of tree mortality have led to an increase in physiological stress and a decrease in survival among fishers (Kordosky 2019). Although the winter of 2016-2017 experienced greater than average levels of precipitation, the high levels of tree mortality are irreversible (Young et al. 2017). If tree mortality continues to increase over the next few years, and as dead trees fall, then the amount of dense canopy cover available will continue to decrease (van Mantgem et al. 2009). Kotler (1984) showed that loss of canopy cover can lead to an increase in exposure to predation, suggesting that canopy cover loss could increase fisher depredation by mountain lions or decrease the abilities of fishers to hunt small mammals. Furthermore, decreased canopy cover due to tree mortality may also increase the ambient air temperature or temperatures within reproductive dens due to lack of shade.
Kilpatrick and Rego (1994) reported fishers selected rest sites in part due to thermoregulation.

By understanding the habitat characteristics of fisher core areas, managers may be able to develop actions to conserve areas of dense canopy cover that may serve as refugia for fishers. As female fishers have a mean core of about $2 \mathrm{~km}^{2}$, we recommend identifying and maintaining forest patches of this size that contain conifer forest with dense canopy cover and have little or no human disturbance (i.e., few or no roads and buildings). Efforts to protect these areas from future wild fires and human disturbance, as well as habitat improvements in these areas, would likely be beneficial to fishers in this region. Additionally, future studies should continue to monitor this population for changes in land use as climate change progresses.

\section{Acknowledgements}

Funding and logistical support provided by the U.S. Department of Agriculture, Forest Service, Pacific Southwest Research Station, and the U.S. Department of Agriculture, Wildlife Services, National Wildlife Research Center. We thank R. Green, N. Hebert, T. Smith, B. Nichols, J. Latter, L. Van Vranken, L. Moon, J. Heiman, L. Kerschner, R. Eng, E. Wood, C. Burt, B. Swanson, and E. Paton for field assistance, and D.N. Koons and two anonymous reviewers for review of the manuscript. The findings and conclusions in this publication have not been formally disseminated by the U.S. Department of Agriculture and should not be construed to represent any agency determination or policy. Furthermore, reference to trade names does not imply endorsement by the U.S. Government.

\section{References}

Allen, C.D., Macalady, A.K., Chenchouni, H., Bachelet, D., McDowell, N., Vennetier, M., et al. 2010. A global overview of drought and heat-induced tree mortality reveals emerging climate change risks for forests. For. Ecol. Manage. 259: 660-684. doi:10.1016/j.foreco.2009.09.001.

Allen-Diaz, B., Standiford, R., and Jackson, R.D. 2007. Oak woodlands and forests. In Terrestrial vegetation of California. 3rd ed. Edited by M.G. Barbour, T. Keeler-Wolf, and A.A. Schoenherr. University of California, Berkeley. pp. 313-338. doi:10.1525/california/9780520249554.003.0012.

Arnould, J.P.Y., Monk, J., Ierodiaconou, D., Hindell, M.A., Semmens, J., Hoskins, A.J., et al. 2015. Use of anthropogenic sea floor structures by Australian fur seals: potential positive ecological impacts of marine industrial development? PLoS ONE, 10: e0130581. doi:10.1371/journal. pone.0130581. PMID:26132329.

Asensio, N., Schaffner, C.M., and Filippo, A. 2012. Variability in core areas of spider monkeys (Ateles geoffroyi) in a tropical dry forest in Costa Rica. Primates, 53: 147-156. doi:10.1007/s10329-011-0288-9. PMID:22094367.

Asner, G.P., Brodrick, P.G., Anderson, C.B., Vaughn, N.R., Knapp, D.E., and Martin, R.E. 2016. Progressive forest canopy water loss during the 20122015 California drought. Proc. Natl. Acad. Sci. U.S.A. 113: E249-E255. doi:10.1073/pnas.1523397113. PMID:26712020.

Aubry, K.B., Raley, C.M., Buskirk, S.W., Zielinski, W.J., Schwartz, M.K., Golightly, R.T., et al. 2013. Meta-analyses of habitat selection by fishers at resting sites in the Pacific coastal region. J. Wildl. Manage. 77(5): 965974. doi:10.1002/jwmg.563.

Bart, R.R., Tague, C.C., and Moritz, M.A. 2016. Effect of tree-to-shrub type conversion in lower montane forests of the Sierra Nevada (USA) on streamflow. PLoS ONE, 11: e0161805. doi:10.1371/journal.pone.0161805. PMID:27575592.

Bŏrger, L., Dalziel, B.D., and Fryxell, J.M. 2008. Are there general mechanisms of animal home range behavior? A review and prospects for future research. Ecol. Lett. 11: 637-650. doi:10.1111/j.1461-0248.2008.01182.x. PMID: 18400017.

Burt, W.H. 1943. Territoriality and home range concepts as applied to mammals. J. Mammal. 24: 346-352. doi:10.2307/1374834.

Carroll, C. 2007. Interacting effects of climate change, landscape conversion, and harvest on carnivore populations at the range margin: marten and lynx in the northern Appalachians. Conserv. Biol. 21(4): 1092-1104. doi:10.1111/ j.1523-1739.2007.00719.x. PMID:17650258.

Dale, V.H., Joyce, L.A., Mcnulty, S., Neilson, R.P., Ayres, M.P., Flannigan, M.D., et al. 2001. Climate change and forest disturbances: climate change can affect forests by altering the frequency, intensity, duration, and timing of fire, drought, introduced species, insect and pathogen outbreaks, hurricanes, windstorms, ice storms, or landslides. BioScience, 51: 723-734. doi:10.1641/ 0006-3568(2001)051[0723:CCAFD]2.0.CO;2. 
Davis, F.W., Seo, C., and Zielinski, W.J. 2007. Regional variation in homerange-scale habitat models for fisher (Martes pennanti) in California. Ecol. Appl. 17(8): 2195-2213. doi:10.1890/06-1484.1. PMID:18213963.

De Luca, D.W., Phillipps, G.P., Machaga, S.J., and Davenport, T.R.B. 2010. Home range, core areas and movement in the 'critically endangered' kipunji (Rungwecebus kipunji) in southwest Tanzania. Afr. J. Ecol. 48(4): 895-904. doi:10.1111/j.1365-2028.2009.01189.x.

Douglas, C.W., and Strickland, M.A. 1987. Fisher. In Wild furbearer management and conservation in North America. Edited by M. Novak, J.A. Baker, M.E. Obbard, and B. Malloch. Ontario Ministry of Natural Resources, Toronto, Ont. pp. 511-530.

Ewer, R.F. 1968. Ethology of mammals. Logos Press, London.

Fettig, C.J., Mortenson, L.A., Bulaon, B.M., and Foulk, P.B. 2019. Tree mortality following drought in the central and southern Sierra Nevada, California, U.S. For. Ecol. Manage. 432: 164-178. doi:10.1016/j.foreco.2018.09.006.

Franklin, J.P., and Fites-Kaufman, J. 1996. Assessment of late-successional forests of the Sierra Nevada. Sierra Nevada Ecosystem Project: Final report to Congress, vol. II, Assessments and scientific basis for management options. University of California, Centers for Water and Wildland Resources, Davis.

Gilchrist, J.S., and Otali, E. 2002. The effects of refuse-feeding on homerange use, group size, and intergroup encounters in the banded mongoose. Can. J. Zool. 80(10): 1795-1802. doi:10.1139/z02-113.

Green, R.E., Purcell, K.L., Thompson, C.M., Kelt, D.A., and Wittmer, H.U. 2018. Reproductive parameters of the fisher in the southern Sierra Nevada, California. J. Mammal. 99: 537-553. doi:10.1093/jmammal/gyy040.

Grinnell, J., Dixon, J.S., and Linsdale, L.M. 1937. Fur-bearing mammals of California: their natural history, systematic status and relations to man. Vol. 1. University of California Press, Berkeley.

Hall, E.R. 1942. Gestation period in the fisher with recommendations for the animal's protection in California. Calif. Fish Game, 28: 143-147.

Harris, S., Cresswell, W.J., Forde, P.G., Trewhella, W.J., Woollard, T., and Wray, S. 1990. Home-range analysis using radio-tracking data-a review of problems and techniques particularly as applied to the study of mammals. Mammal Rev. 20: 97-123. doi:10.1111/j.1365-2907.1990.tb00106.x.

Heilman, G.E., Strittholt, J.R., Slosser, N.C., and Dellasala, D.A. 2002. Forest fragmentation of the conterminous United States: assessing forest intactness through road density and spatial characteristics: forest fragmentation can be measured and monitored in a powerful new way by combining remote sensing, geographic information systems, and analytical software. BioScience, 52: 411-422. doi:10.1641/0006-3568(2002)052[0411:FFOTCU]2.0.CO;2.

Hoegh-Guldberg, O., Hughes, L., McIntyre, S., Lindenmayer, D.B., Parmesan, C., Possingham, H.P., and Thomas, C.D. 2008. Assisted colonization and rapid climate change. Science, 321: 345-346. doi:10.1126/science.1157897. PMID: 18635780.

Holbrook, J.D., Squires, J.R., Olson, L.E., Lawrence, R.L., and Savage, S.L. 2016. Multiscale habitat relationships of snowshoe hares (Lepus americanus) in the mixed conifer landscape of the Northern Rockies, U.S.A.: Cross-scale effects of horizontal cover with implications for forest management. Ecol. Evol. 7: 125-144. doi:10.1002/ece3.2651. PMID:28070281.

Holbrook, J.D., Squires, J.R., Bollenbacher, B., Graham, R., Olson, L.E., Hanvey, G., et al. 2019. Management of forests and forest carnivores: relating landscape mosaics to habitat quality of Canada lynx at their range periphery. For. Ecol. Manage. 437: 411-425. doi:10.1016/j.foreco.2019.01.011.

Hopkinson, P., and Battles, J.J. 2015. Learning how to apply adaptive management in the Sierra Nevada forests: an integrated assessment. Final report of the Sierra Nevada Adaptive Management Project. Center for Forestry, University of California, Berkeley.

Johnson, M.R., Polak, K., and von Gontard, C. 2018. Humane canine handling, capture, and transportation. Field Manual for Small Anim. Med. 4: 47-70. doi:10.1002/9781119380528.ch4.

Kaufmann, J.H. 1962. Ecology and social behavior of the coati, Nasua narica, on Barro Colorado Island, Panama. Univ. Calif. Publ. Zool. 60: 95-222.

Keeley, J.E., and Davis, F.W. 2007. Chaparral. In Terrestrial vegetation of California. 3rd ed. Edited by M.G. Barbour, T. Keeler-Wolf, and A.A. Schoenherr. University of California Press, Berkeley. pp. 339-366. doi:10.1525/california/ 9780520249554.003.0013.

Kilpatrick, H.J., and Rego, P.W. 1994. Influence of season, sex, and site availability on fisher (Martes pennanti) rest-site selection in the central hardwood forest. Can. J. Zool. 72(8): 1416-1419. doi:10.1139/z94-187.

Knaus, B.J., Cronn, R., Liston, A., Pilgrim, K., and Schwartz, M.K. 2011. Mitochondrial genome sequences illuminate maternal lineages of conservation concern in a rare carnivore. BMC Ecol. 11(10): 10. doi:10.1186/1472-6785-11-10. PMID:21507265.

Kordosky, J.R. 2019. Landscape of stress: does drought prevail over anthropogenic activity in influencing cortisol levels and fitness in the Pacific fisher? MS thesis, Utah State University, Logan.

Kotler, B.P. 1984. Risk of predation and the structure of desert rodent communities. Ecology, 65: 689-701. doi:10.2307/1938041.

Laver, P.N., and Kelly, M.J. 2008. A critical review of home range studies. J. Wildl. Manage. 72: 290-298. doi:10.2193/2005-589.

Leuthold, W. 1977. African ungulates: a comparative review of their ethology and behavioral ecology. Springer-Verlag, Berlin, Heidelberg, Germany.
Levine, S. 2000. Influence of psychological variables on the activity of the hypothalamic-pituitary-adrenal axis. Eur. J. Pharmacol. 405: 149-160. doi:10.1016/S0014-2999(00)00548-3. PMID:11033322.

Lewis, J.C., and Zielinski, W.J. 1996. Historical harvest and incidental capture of fishers in California. Northwest Sci. 70: 291-297.

Mancinelli, S., Boitani, L., and Ciucci, P. 2018. Determinants of home range size and space use patterns in a protected wolf (Canis lupus) population in central Apennines, Italy. Can. J. Zool. 96(8): 828-838. doi:10.1139/cjz-2017-0210.

Manley, P.N., Gutierrez, R.J., and Stine, P. 2017. The California spotted owl: current state of knowledge. USDA Forest Service, General Technical Report PNW.

McKelvey, K.S., and Johnston, J.D. 1992. Historical perspectives on forests of the Sierra Nevada and the transverse ranges of southern California; forest conditions at the turn of the century. In The California spotted owl: a technical assessment of its current status. Edited by J. Verner, K.S. McKelvey, B.R. Noon, R.J. Gutierrez, G.I. Gould, and T.W. Beck. U.S. Forest Service, Pacific Southwest Research Station, Gen. Tech. Rep. PSW-GTR-133. pp. 225-246.

Morelli, T.L., Daly, C., Dobrowski, S.Z., Dulen, D.M., Ebersole, J.L., Jackson, S.T., et al. 2016. Managing climate change refugia for climate adaptation. PLoS ONE, 11(8): e0159909. doi:10.1371/journal.pone.0159909. PMID:27509088.

Plowman, B.W., Conner, L.M., Chamberlain, M.J., Leopold, B., and Burger, L.W. 2006. Annual dynamics of bobcat (Lynx rufus) home range and core use areas in Mississippi. Am. Midl. Nat. 156: 386-393. doi:10.1674/0003-0031(2006) 156[386:ADOBLR]2.0.CO;2.

Powell, R.A. 2000. Animal home ranges and territories and home range estimators. In Research techniques in animal ecology: controversies and consequences. Edited by M.C. Pearl, L. Boitani, and T. Fuller. Columbia University Press, New York. pp. 65-110.

Purcell, K.L., Mazzoni, A.K., Mori, S.R., and Boroski, B.B. 2009. Resting structures and resting habitat of fishers in the southern Sierra Nevada, California. For. Ecol. Manage. 258: 2696-2706. doi:10.1016/j.foreco.2009.09.041.

Rangel-Negrin, A., Alfaro, J.L., Valdez, R.A., Romano, M.C., and Serio-Silva, J.C. 2009. Stress in Yucatan spider monkeys: effects of environmental conditions on fecal cortisol levels in wild and captive populations. Anim. Conserv. 12: 496-502. doi:10.1111/j.1469-1795.2009.00280.x.

R Core Team. 2016. R: a language and environment for statistical computing. R Foundation for Statistical Computing, Vienna, Austria. Available from https://www.r-project.org.

Roemer, G.W., Gompper, M.E., and Van Valkenburgh, B. 2009. The ecological role of the mammalian mesocarnivore. BioScience, 59: 165-173. doi:10.1525/ bio.2009.59.2.9.

Sauder, J.D., and Rachlow, J.L. 2015. Forest heterogeneity influences habitat selection by fishers (Pekania pennanti) within home ranges. For. Ecol. Manage. 347: 49-56. doi:10.1016/j.foreco.2015.03.009.

Schempf, P.F., and White, M. 1977. Status of six furbearer populations in the mountains of northern California. Department of Forestry and Conservation, and Museum of Vertebrate Zoology, University of California, Berkeley.

Seglund, A.E. 1995. The use of resting sites by the Pacific fisher. Master's thesis, Humboldt State University, Arcata, Calif.

Silva-Opps, M., and Opps, S. 2011. Use of telemetry data to investigate home range and habitat selection in mammalian carnivores. In Modern telemetry. Edited by K. Ondrej. IntechOpen Limited, London. pp. 281-308. doi:10.5772/ 25221.

Spencer, W., Rustigian-Romsos, H., Strittholt, J., Scheller, R., Zielinski, W., and Truex, R. 2011. Using occupancy and population models to assess habitat conservation opportunities for an isolated carnivore population. Biol. Conserv. 144: 788-803. doi:10.1016/j.biocon.2010.10.027.

Stephens, S.I., Collins, B.M., Fettig, C.J., Finney, M.A., Hoffman, C.M., Knapp, E., et al. 2018. Drought, tree mortality, and wildfire in forests adapted to frequent fire. Bioscience, 68: 77-88. doi:10.1093/biosci/bix146.

Sweitzer, R.A., Popescu, V.D., Thompson, C.M., Purcell, K.L., Barrett, R.H., Wengert, G.M., et al. 2016a. Mortality risks and limits to population growth of fishers. J. Wildl. Manage. 80(3): 438-451. doi:10.1002/jwmg.1020.

Sweitzer, R.A., Furnas, B.J., Barrett, R.H., Purcell, K.L., and Thompson, C.M. $2016 b$. Landscape fuel reduction, forest fire, and biophysical linkages to local habitat use and local persistence of fishers (Pekania pennanti) in Sierra Nevada mixed-conifer forests. For. Ecol. Manage. 361: 208-225. doi:10.1016/j.foreco.2015.11.026.

Thompson, C.M., Zielinski, W.J., and Purcell, K.L. 2011. Evaluating management risks using landscape trajectory analysis: A case study of California fisher. J. Wildl. Manage. 75: 1164-1176. doi:10.1002/jwmg.159.

Tucker, J.M., Schwartz, M.K., Truex, R.L., Pilgrim, K.L., and Allendorf, F.W. 2012. Historical and contemporary DNA indicate fisher decline and isolation occurred prior to the European settlement of California. PLoS ONE, 7: e52803. doi:10.1371/journal.pone.0052803. PMID:23300783.

Tucker, J.M., Allendorf, F.W., Truex, R.L., and Schwartz, M.K. 2017. Sex-biased dispersal and spatial heterogeneity affect landscape resistance to gene flow in fisher. Ecosphere, 8: e01839. doi:10.1002/ecs2.1839.

U.S. Fish and Wildlife Service. 2014. Endangered and threatened wildlife and plants; threatened species status for West Coast Distinct Population Segment. Proposed Rule. Fed. Regist. 79: 60419-60425.

U.S. Fish and Wildlife Service. 2019. Endangered and threatened wildlife and plants: threatened species status for West Coast Distinct Population Segment of fisher with Section 4(d) Rule. Fed. Regist. 84(216): 6027860305. 
van Mantgem, P.J., Stephenson, N.L., Byrne, J.C., Daniels, L.D., Franklin, J.F., Fule, P.Z., et al. 2009. Widespread increase of tree mortality rates in the western United States. Science, 323: 521-524. doi:10.1126/science.1165000. PMID:19164752.

Weaver, J.L., Paquet, P.C., and Ruggiero, L.F. 1996. Resilience and conservation of large carnivores in the Rocky Mountains. Conserv. Biol. 10(4): 964-976. doi:10.1046/j.1523-1739.1996.10040964.x.

Wengert, G., Gabriel, M., Matthews, S., Higley, J.M., Sweitzer, R.A., Thompson, C.M., et al. 2014. Using DNA to describe and quantify interspecific killing of fishers in California. J. Wildl. Manage. 78: 603-611. doi:10.1002/jwmg.698.

White, G.C., and Garrott, R.A. 1990. Analysis of wildlife radio-tracking data. Academic Press, Cambridge, Mass.

Wilbert, C.J. 1992. Spatial scale and seasonality of habitat selection by martens in southeastern Wyoming. MS thesis, University of Wyoming, Laramie.

Wingfield, J.C. 2008. Comparative endocrinology, environment and global change. Gen. Comp. Endocrinol. 157: 207-216. doi:10.1016/j.ygcen.2008.04.017. PMID:18558405.

Wingfield, J.C. 2013. Ecological processes and the ecology of stress: the impacts of abiotic environmental factors. Funct. Ecol. 27: 37-44. doi:10.1111/13652435.12039 .
Worton, B.J. 1989. Kernel methods for estimating the utilization distribution in home-range studies. Ecology, 70: 164-168. doi:10.2307/1938423.

Young, D.J.N., Stevens, J.T., Earles, J.M., Moore, J., Ellis, A., Jirka, A.L., and Latimer, A.M. 2017. Long-term climate and competition explain forest mortality patterns under extreme drought. Ecol. Lett. 20: 78-86. doi:10.1111/ ele.12711. PMID:28000432.

Zhao, F., Sweitzer, R.A., Guo, Q., and Kelly, M. 2012. Characterizing habitats associated with fisher den structures in the southern Sierra Nevada, California using discrete return lidar. For. Ecol. Manage. 280: 112-119. doi:10.1016/j. foreco.2012.06.005.

Zielinski, W.J., Duncan, N.P., Farmer, E.C., Truex, R.L., Clevenger, A.P., and Barrett, R.H. 1999. Diet of fishers (Martes pennanti) at the southernmost extent of their range. J. Mammal. 80: 961-971. doi:10.2307/1383266.

Zielinski, W.J., Thompson, C.M., Purcell, K.L., and Garner, J.D. 2013. An assessment of fisher (Pekania pennanti) tolerance to forest management intensity on the landscape. For. Ecol. Manage. 310: 821-826. doi:10.1016/j. foreco.2013.09.028. 